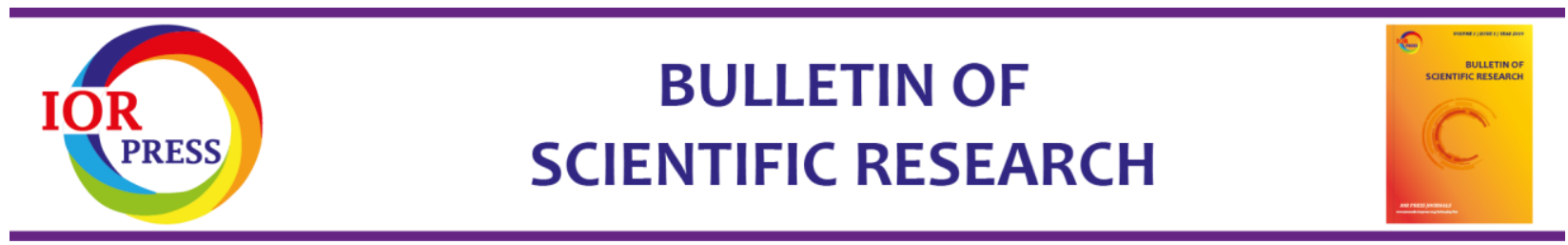

\title{
Fatty acid profile, antioxidant and antibacterial effect of the ethyl acatate extract of cleistopholis patens
}

\author{
A.0. Daniels ${ }^{a}$, ${ }^{*}$, Taye Temikotan ${ }^{b}$ \\ a Department of Biological Sciences, College of Natural and Applied Sciences, Achievers University, Owo, \\ Ondo State, Nigeria.
}

*Corresponding Author: toyosidanny@yahoo.com DOI: https://doi.org/10.34256/bsr2113

Received: 12-01-2021

Accepted: 07-02-2021

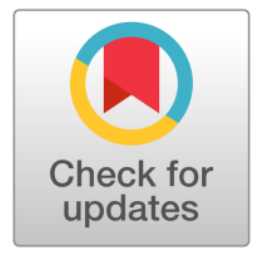

\begin{abstract}
Cleistopholis patens is a tropical plant that is used in the treatment of many bacterial and fungal infections. In this study, the antibacterial action against some human pathogens and the fatty acid profile of the plant were investigated. The plant was found to be active against Salmonella typhi Streptococcus pyogenes, Staphylococcus aureus while Shigella dysenteriae was resistant. The comparative antibiotic test revealed that only Staphylococcus aureus was sensitive to chloramphenicol and gentamycin. The purified extract showed lesser activity than the crude extract. Phytochemical components include; glycosides, steroids, Phenol, tanins and saponins. Anticonstituents include tanin $(2.32 \mathrm{mg} / \mathrm{g})$, phenol $(2.50 \mathrm{mg} / \mathrm{g})$, phytate $(15.65 \mathrm{mg} / \mathrm{g})$, oxalate $(6.57 \mathrm{mg} / \mathrm{g})$, saponin $(9.71 \mathrm{mg} / \mathrm{g})$ and flavonoids $(6.49 \mathrm{mg} / \mathrm{g})$. The GCMS profile of the ethyl acetate extract of the plant revealed 23 fatty acid including 9Hexadecanoic acid, (25.11\%), 6 octadecanoic acid (21.98\%), n Hexadecanoic (4.62\%), Cyclopentaneundecanoic acid, methyl ester (2.05\%). Heptacosanoic acid, methyl ester (2.05\%), Decanoic acid, methyl ester (1.74\%), Oleic acid (4.38\%), 16-Octadecenoic acid, methyl ester (3.55\%) amongst others.
\end{abstract}

Keywords: Cleistopholis patens, Antibacterial, Phytochemicals, Fatty acids, Antinutrients.

\section{Introduction}

New metabolites from plants are discovered every year in an attempt to discover new antimicrobial compounds due to the high rate of resistance of microorganisms to standard antibiotics [1]. Fatty acids are molecules typically found attached to other compounds such as sugars, glycerol or phosphate head groups to form lipids [2] and many are known to have originated from unusual biosynthetic pathways, thus displaying unusual characteristic of unsaturated patterns, exhibit terminal and/or mid-chain branching [1]. Lipids are essential components of cell structures like the cell membranes, which are main components of phospholipids, and energy stores that are often composed of triglycerides. Fatty acids are released from lipids, typically by the action of enzymes, to become free fatty acids, which have vast and potent biological activities [3]. Plants are rich sources of beneficial secondary metabolites which are attractive as pharmaceuticals, antimicrobials, flavours, fragrances, and pesticides. Among these herbal constituents, fatty acids, antioxidants, and antibacterial compounds play very important role in maintaining health and improving the quality of human life $[4,5]$ revealed that medicinal plants are very good 
sources of antioxidants and are reported to play a major role in the treatment of infectious diseases in humans.

Cleistopholis patens is a tropical tree originating from Sierra Leone eastwards into Uganda and Zaire. It is a sun loving fast growing plant and belongs to the family Annonaceae and genus Cleistopholis (Pierre ex England). It has slender cylindrical and straight bole. The plant is known for its medicinal properties in the treatment of various diseases. Bark decoctions are taken to treat stomach-ache, diarrhoea, tuberculosis, bronchitis and hepatitis. Bark pulp is applied against swellings, oedema and whitlow, and bark sap is dropped into the nose to treat headache and rubbed in to treat rickets in children. In Uganda, crushed bark is used in preparations to treat malaria and measles. In Nigeria, the bark is used to treat typhoid fever and bark extracts are used in the treatment of menstrual irregularities. The root bark is used as vermifuge. Leaf infusions or decoctions are administered against hepatitis, fever, trypanosomiasis and rheumatic arthritis, and as vermifuge [6].

\section{Materials and Methods}

\subsection{Sampling and preparation of plant sample}

Stem bark of Cleistopholis patens were purchased from a herb market in Owo, Ondo State and a taxonomist of Achievers University, Owo. identified the plant.

\subsection{Determination of the yield of crude extract}

The percentage yield of the extracts was determined by weighing the powdered plant before extraction and the crude extracts weighed after extraction and the values were then calculated using the expression according to [7].

$$
\begin{aligned}
& \text { Percentage (\%)yield } \\
& =\frac{\text { Weight }(\mathrm{g}) \text { of the concentrated extracts }}{\text { Weight }(\mathrm{g}) \text { of the ground plant extracts }} \text { X100 }
\end{aligned}
$$

\subsection{Collection and maintenance of microorganisms}

Strains of Salmonella typhi, Streptococcus pyogenes, Shigella dysenteriae and Staphylococcus aureus were collected from Obafemi Awolowo University, Ile Ife, Osun state and maintained on nutrient agar slants.

\subsection{Standardization of inocula}

Inocula were standardized to attain the McFarland constant which was prepared from Barium sulphate

\subsection{Extraction procedure}

The plant particles was macerated in ethyl acetate for five days under constant agitation using the methods of [8]. The solution was thereafter filtered and evaporated to dryness in the rotary evaporator. The crude extract was suspended in DMSO and sterilized by passing through $s$ milipore membrane filter with pore size $0.45 \mu \mathrm{m}$. the sterile extract is then kept in sterile bottles until use.

\subsection{Phytochemical screening of plant}

Active plants were screened qualitatively for phytochemicals using the methods of [9-11].

\section{Test for alkaloids}

A $0.2 \mathrm{~g}$ amount of plant extract was acidified with $1 \%$ hydrochloric acid ( $\mathrm{HCl})$ for 2 min and was then treated with a few drops of Dragendorff's reagent in a test tube. The formation of white precipitate indicates the presence of alkaloids. 


\section{Test for saponins}

Sterile distilled water was used to dissolve $0.2 \mathrm{~g}$ of plant extract. A $2 \mathrm{ml}$ amount of the solution was placed in different test tubes and was shaken vigorously for a few minutes. Frothing which persists on warming was taken as an evidence of the presence of saponin.

\section{Test for tannins (Gelatin test)}

To the extract, $1 \%$ gelatin solution containing sodium chloride was added. Formation of white precipitate indicates the presence of tannins.

\section{Test for flavonoids (Shinoda's Tests)}

Plant extract was dissolved in $2 \mathrm{ml}$ of dilute $\mathrm{NaOH}$. A yellow solution that turns faint or colourless on addition of a few drops of hydrochloric acid and a change in colour while standing indicates the presence of flavonoids.

\section{Test for cardiac glycosides (Liberman's Test)}

The Liberman's test was used to determine the presence of cardiac glycosides. A $5 \mathrm{~g}$ amount of plant extract was dissolved in $20 \mathrm{ml}$ of acetic anhydride and cooled with ice. Concentrated $\mathrm{H}_{2} \mathrm{SO}_{4}$ was then carefully added. A colour change from violet to blue and then to green indicated the presence of a steroidal nucleus (a glycone portion of the cardiac glycoside).

\section{Test for steroids (Salkowski test)}

A $0.5 \mathrm{~g}$ portion of plant extract was dissolved in $2 \mathrm{ml}$ of chloroform and $0.2 \mathrm{ml}$ of concentrated $\mathrm{H}_{2} \mathrm{SO}_{4}$ was carefully added to form a layer. A reddish -brown colour ring at the interface between the layers indicated the deoxy- sugar characteristic of cadenolides which indicated the presence of steroids.

\subsection{Bioassay guided fractionation of plant extract}

The method of [12] was adopted. The crude extract of $(1.5 \mathrm{~g})$ was dispersed in $10 \mathrm{ml}$ of petroleum ether. A $60 \mathrm{gm}$ amount of $60-120$ mesh silica gel was used to pack the column by as the stationary phase while varying solvent combinations of increasing polarity were used as the mobile phase. The plant extract on top of the column. And the mobile phase added. The column tap was opened to allow the eluent to flow at the rate of 40 drops per minute. Elution of the extract was done with solvent systems of increasing polarity using petroleum ether, chloroform, ethyl acetate and methanol. Aliquot of $100 \mathrm{ml}$ were collected and each aliquot was allowed to run through a short column and the fractions were collected. The purity was tested in each case by spotting in TLC plate. Elution of a single compound on the TLC plate confirmed a single pure compound.

\subsection{Evaluation of Antibacterial effect of crude and purified extract}

The agar well diffusion method of [13]. Test organisms were suspended in Nutrient broth and incubated for 4 hours to obtain a concentration corresponding to McFarlands constant $\left(0.5 \times 10^{8} \mathrm{cfu} / \mathrm{ml}\right)$. The inocula were standardized with barium sulphate. Sterile Petri dishes were inoculated by the pour plate method. One $\mathrm{ml}(1 \mathrm{ml})$ of the test inoculum was pipetted aseptically into each Petri dish and about $20 \mathrm{ml}$ of sterilized nutrient agar was poured into the inoculated Petri dish. The agar plates were allowed to set. Wells of $6 \mathrm{~mm}$ diameter were made over the agar plates equidistant from each other using a sterile cork borer and $0.5 \mathrm{ml}$ of plant extracts Crude and purified extracts added separately to the wells using a micropipette. The extracts were allowed to diffuse into the agar for about 20 minutes after which the plates were incubated for $24 \mathrm{~h}$ at $37^{\circ} \mathrm{C}$. Thereafter, the diameter of inhibition zones formed around each well was 
measured in $\mathrm{mm}$ and recorded. The experiments were carried out in triplicates and the average values recorded.

\subsection{Determination of Antibiotics sensitivity}

Gram-positive and Gram-negative susceptibility testing using standard antibiotics; Gentamycin (10 $\mu \mathrm{g})$, and chloramphenicol $(10 \mu \mathrm{g})$ were carried out using the disk diffusion method of [14]. Nutrient agar plates were prepared and seeded with bacterial inoculum using the pour plate method. After gelling, antibiotic disk were placed on the gelled plate and the plates were incubated at $37^{\circ} \mathrm{C}$ for $24 \mathrm{hr}$ after which the zones of inhibition were observed and recorded.

\subsection{Estimation of chemical components of purified extract using GCMS}

Ethyl acetate extract of Stem bark $C$. patens was analyzed with the help of GC-MS analyzer (Perkin Elmer Gas ChromatographyMass Spectrum) using the method [14]. On Elite-1 column the date was generated. The carrier gas helium (99.999\%) was used at flow rate of $1 \mathrm{ml}$ per min in split mode (10:1). $8 \mu$ of sample was injected to column at $250^{\circ} \mathrm{C}$ injector temperature. Temperature of oven starts at $60^{\circ} \mathrm{C}$ and hold for $6 \mathrm{~min}$ and then it was raised at rate of $10^{\circ} \mathrm{C}$ per min to $300^{\circ} \mathrm{C}$ without holding. Holding was allowed for $6 \mathrm{~min}$ at program rate of $5^{\circ} \mathrm{C}$ per minute while the temperature of ion sources was maintained at $240^{\circ} \mathrm{C}$. The injector temperature was set at $250^{\circ} \mathrm{C}$ and detector temperature was set at $260^{\circ} \mathrm{C}$. The mass Spectrum of compounds present in samples was obtained by electron ionization at $70 \mathrm{eV}$ and detector operates in scan mode 50 to $600 \mathrm{Da}$ atomic units. A 0.5 seconds of scan interval and fragments from 50 to $600 \mathrm{Da}$ was maintained. Total running was 40 minutes.

\subsection{Result and discussion}

\subsection{Yield of plant}

The percentage yield for the ethyl acetate $C$. patens was $2.82 \%$. The percentage yield of plants depend on varied environmental and physiological conditions, age of plant and the extraction medium and methods. The presence of different compounds of varied chemical characteristics and polarities that may also be a strong factor in the yield of a plant. [7, 16]. Ethyl acetate is a moderately polar solvent with a polarity index of 0.228 [8] which accounted for the low yield of the solvent because ethyl acetate extract less polar compounds.

\subsection{Antibacterial activity of the crude and purified extract of $C$. patens}

The antibacterial activity of the extract of $C$. patens is presented in table 1 . The extracts was active against Salmonella typhi, Streptococcus pyogenes, Staphylococcus aureus but was not active against Shigella dysenteriae. The antibacterial activity exhibited is not unconnected with the phytochemical content of the plant. [17] reported antibacterial activity of the ethanol and aqueous extract of $C$. patens against E. coli, $S$ aureus, $S$. typhi.. The antibacterial activity of the purified extract was low as compared with the crude extract. This is explainable by the fact that most active components of plants work in synergy to effect maximum efficacy.

[18] established the interaction and pharmacodynamics interaction between various constituents of Artemisia annua. [19] also stated that pure drugs rarely have the same degree of efficacy as crude drugs. Plants survive the environmental hazard because they produce an array of phytochemicals. If plants produce single items to protect themselves, they may not survive long in the environment. 
Table 1. Antibacterial activity of ethyl acetate extracts of crude and purified extracts of $\mathrm{C}$. patens.

\begin{tabular}{|l|l|l|l|l|}
\hline Extracts & $\begin{array}{l}\text { Salmonella } \\
\text { typhi }\end{array}$ & $\begin{array}{l}\text { Streptococcus } \\
\text { pyogenes, }\end{array}$ & $\begin{array}{l}\text { Staphylococcus } \\
\text { aureus }\end{array}$ & $\begin{array}{l}\text { Shigella } \\
\text { dysenteriae. }\end{array}$ \\
\hline Crude extract & 20 & 22 & 14 & - \\
\hline Purified extract & 8 & 14 & 13 & - \\
\hline Chloramphenicol & - & - & $28(\mathrm{~S})$ & - \\
\hline Gentamycin & - & 14 & $28(\mathrm{~S})$ & - \\
\hline
\end{tabular}

Legend; - means no activity.

Table 2. Phytochemical components plant

\begin{tabular}{|c|c|c|c|c|c|c|}
\hline & \multicolumn{5}{|c|}{ Chemical composition in mg/g } \\
\hline Plant & Tannins & Phenols & Phytates & Oxalates & Saponins & Flavonoids \\
\hline C.patens & 2.20 & 3.50 & 17.30 & 3.69 & 13.89 & 9.89 \\
\hline
\end{tabular}

The comparative antibiotic assay showed that only $S$. aureus was sensitive to both chloramphenicol and gentamycin, According to NSCL standard, chloramphenicol must exhibit zone of inhibition of $\geq 18$ to be adjudged to be sensitive while gentamycin must attain a zone of inhibition of $\geq 15$ is said to be sensitive but values $\geq 12$ can be said to have mild activity.

\subsection{Phytochemical components of Plant}

Cleistopholis patens contains glycosides, steroids, phenols, tanins and saponins (Table 2). The antibacterial activity of the plant extract in this study can be attributed to the presence of various bioactive components. Secondary metabolites affect multiple targets, with membrane effects being a common theme may manifest as physical disruption and leakage of cell contents, disruption of membrane ion gradients, and/or permeabilising effects resulting in enhanced uptake of the biocide itself into the cell interior [20-22]. The presence of these chemical compound exhibit multiple biological properties including antimicrobial, cytotoxic, act as powerful antioxidants activity and antiinflammatory [23]. Anti nutrients in C. patens include tanin $(2.32 \%)$, phenol (2.50\%), phytate $(15.65 \%)$, oxalate $(6.57 \%)$, saponin $(9.71 \%)$ and flavonoids (6.49\%).

Antinutrients are natural or synthetic compounds that interfere with the absorption of nutrients [24]. Some of the common symptoms exhibited by a large number of antinutrients in the body can be nausea, bloating, headaches, rashes, nutritional deficiencies [25]. Although, secondary metabolites, acting as anti-nutrients, elicit very harmful biological responses, some of them are widely applied in nutrition and as pharmacologically-active agents [26]. However, when used in small quantities, phytate, lectins, tannins, amylase inhibitors and saponins have been shown to reduce blood glucose and insulin responses to starchy foods and/or the plasma cholesterol and triglycerides (Table 3). 
Table 3 Anti nutrient content of plant

\begin{tabular}{|l|l|l|l|l|l|l|l|}
\hline Plant & Alkaloids & Glycosides & steroids & Anthraquinones & Phenol & Tanin & Saponin \\
\hline C.patens & -ve & +ve & +ve & -ve & +ve & +ve & +ve \\
\hline
\end{tabular}

In addition, phytates, tannins, saponins, protease inhibitors, oetrogens and oxalates have been related to reduce cancer risks [25].

\subsection{Fatty acid content of $C$. patens}

The purified extract of $C$. patens yielded 23 fatty acids (Table 4). Fatty acids are antimicrobial agents that have been reported to destabilize bacterial cell membranes causing wide range of direct and indirect inhibitory effects [27].

Table 4. Presents the fatty acid components of C. patens, Fatty acids identified from the extract include; 9-Hexadecanoic acid, also known as palmitic acid (25.11\%) and 6 octadecanoic acid (21.98\%) occur in copious amount while others occur in minute quantities. Hexadecanoic acid has been documented to have anti-oxidant, hypocholesterolemic, nematicide, antiandrogenic, haemolytic, pesticidal, lubricant, 5Alpha reductase inhibitor, antipsychotic activities $[27,28]$ enumerated the extensive application of fatty acid and monoglyceride derivatives against a wide range of bacteria, including pathogenic strains such as methicillin-resistant Staphylococcus aureus (MRSA). Tetradecanoic acid exhibited antifungal, antioxidant, cancer preventive nematicide, hypercholesterolemic. Other fatty acid identified are known to exhibit antimicrobial activities.

Fatty acids can inhibit the growth microorganisms such as bacteria, protozoans, viruses and fungi [27,29]. Gram positive bacteria are known to be sensitive to fatty acid with few Gram negative specie being susceptible.

The large amount of fatty acid discovered in this plant could be responsible in part for the antibacterial activities. [30-34] discovered in their various works that fatty acids are responsible for the antibacterial properties in the crude extracts of plants. Fatty acids occur mainly in bound form in plants, esterified to glycerol, as fats or lipids [35].

[36] documented that the biological activities of fatty acid is dependent to a large extent on the saturation of the fatty acid. He opined that unsaturated fatty acid showed more antimicrobial activity than saturated fatty acids, he however concluded that the coexistence of saturated fatty acids with unsaturated fatty acids in phagosomes should not interfere with the bactericidal effect of the either acids.

Fatty acids of different chain lengths inhibited the growth of $B$. subtilis as demonstrated by [36] but the effect was reduced in the presence of glycolytic compounds [37]. observed that Gram-negative bacteria are more resistant to inactivation by medium and long chain fatty acids than Grampositive bacteria. 
Table 2 Fatty acid components of the Ethyl acetate extract of $C$. patens

\begin{tabular}{|c|c|c|c|c|c|c|}
\hline RT & Nam of compound & $\begin{array}{l}\text { Molecular } \\
\text { formular }\end{array}$ & MW & $\begin{array}{c}\text { Peak } \\
\text { area } \\
\%\end{array}$ & $\begin{array}{l}\text { Compound } \\
\text { nature }\end{array}$ & Structure \\
\hline 22.383 & N; Hexadecanoic acid & $\mathrm{C}_{16} \mathrm{H}_{32} \mathrm{O}_{2}$ & 256 & 4.62 & & \\
\hline 22.383 & Octadecanoic acid & $\mathrm{C}_{18} \mathrm{H}_{36} \mathrm{O}_{2}$ & 284 & 4.62 & Hysterene & \\
\hline 24.525 & 6, octadecanoic acid & $\mathrm{C}_{18} \mathrm{H}_{34} \mathrm{O}_{2}$ & 282 & 21.98 & Octadecer & \\
\hline 24.525 & 9, Hexadecenoic acid & $\mathrm{C}_{16} \mathrm{H}_{30} \mathrm{O}_{2}$ & 254 & 25.11 & & \\
\hline 17.500 & $\begin{array}{l}\text { Cyclopentaneundecanoic } \\
\text { acid, methyl ester }\end{array}$ & $\mathrm{C}_{17} \mathrm{H}_{32} \mathrm{O}_{2}$ & 268 & 2.05 & & \\
\hline 17.500 & $\begin{array}{l}\text { Heptacosanoic acid, methyl } \\
\text { ester }\end{array}$ & $\mathrm{C}_{28} \mathrm{H}_{56} \mathrm{O}_{2}$ & 424 & 2.05 & & \\
\hline 17.500 & $\begin{array}{l}\text { Tetradecanoic acid, } 12- \\
\text { methyl-, methyl ester }\end{array}$ & $\mathrm{C}_{16} \mathrm{H}_{32} \mathrm{O}_{2}$ & 256 & 2.05 & & 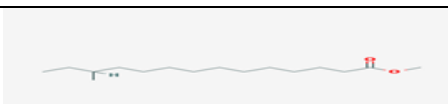 \\
\hline 17.500 & $\begin{array}{l}\text { Heneicosanoic acid, methyl } \\
\text { ester }\end{array}$ & $\mathrm{C}_{22} \mathrm{H}_{44} \mathrm{O}_{2}$ & 340 & 2.05 & & \\
\hline 17.500 & $\begin{array}{l}\text { Tetradecynoic acid, methyl } \\
\text { ester }\end{array}$ & $\mathrm{C}_{15} \mathrm{H}_{26} \mathrm{O}_{2}$ & 238 & 2.05 & & \\
\hline 19.683 & Decanoic acid, methyl ester & $\mathrm{C}_{11} \mathrm{H}_{22} \mathrm{O}_{2}$ & 186 & 1.74 & & \\
\hline 19.683 & Octanoic acid, methyl ester & $\mathrm{C}_{9} \mathrm{H}_{18} \mathrm{O}_{2}$ & 158 & 1.74 & & \\
\hline 19.683 & $\begin{array}{l}\text { Tridecanoic acid, methyl } \\
\text { ester }\end{array}$ & $\mathrm{C}_{14} \mathrm{H}_{28} \mathrm{O}_{2}$ & 228 & 1.74 & & \\
\hline 19.683 & $\begin{array}{l}\text { Hexadecanoic acid, 15- } \\
\text { methyl-, methyl ester }\end{array}$ & $\mathrm{C}_{18} \mathrm{H}_{36} \mathrm{O}_{2}$ & 284 & 1.74 & & \\
\hline
\end{tabular}




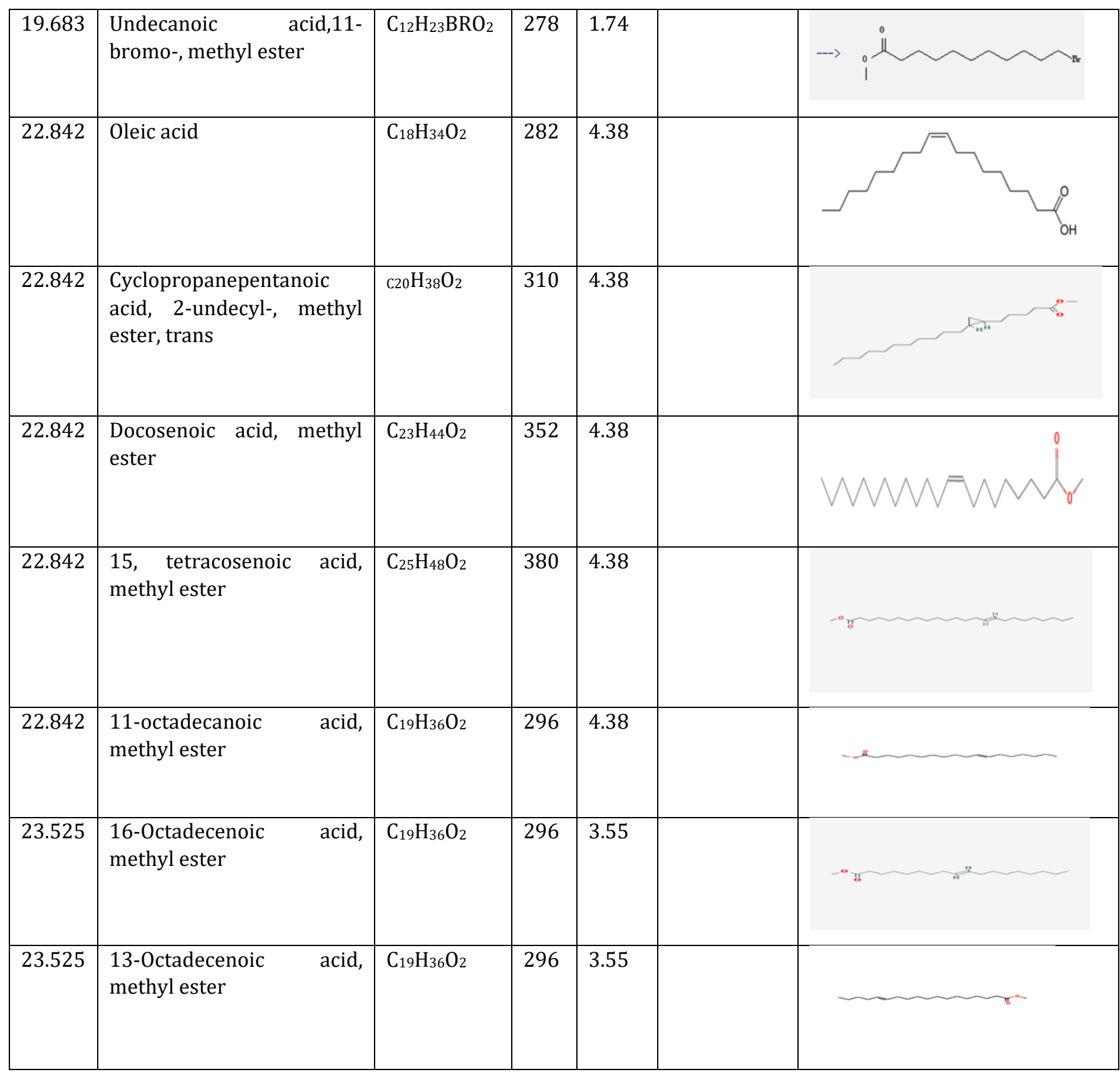

\section{Conclusion}

The plant $C$. patens has interesting antibacterial properties. The copious quantity of fatty acids and possibly other phytochemicals could be responsible for the antibacterial activity of the plant. Therapeutic uses of fatty acids of plant source are a field that should be explored extensively for the treatment of bacterial infections. One of such is the comparative effect of the long and short chain fatty acids including the long-chain poly unsaturated fatty acids. The synergistic effect of fatty acid and other compounds should also be explored. Summarily, the fatty acid from C. patens can be a good source of antibacterial drug therapy. 


\section{References}

[1] Z.M. Rashid, A. M. Ali, P. Douzenel, N. Bourgougnon, K. Shaari, Y. Andriani, T.S.T. Muhammad, H. Mohamad, Phenolics, fatty acids composition and biological activities of various extracts and fractions of Malaysian Aaptos Asian Pacific Journal of Tropical Biomedicine, 8 (2018) 554-564. https://doi.org/10.4103/2221-1691.245971

[2] E. Karimi, H. Z. Jaafar, A. Ghasemzadeh, M. Ebrahimi, Fatty acid composition, antioxidant and antibacterial properties of the microwave aqueous extract of three varieties of Labisia pumila Benth, Biological research, 48 (2015) 1-6.

[3] A.P. Desbois, V.J. Smith, Antibacterial free fatty acids: activities, mechanisms of action and biotechnological potential. Applied Microbiology and Biotechnology, 85 (2010)1629-42. https://doi.org/10.1007/s00253-009-2355-3

[4] R. Tavakoli, M. Mohadjerani, R. Hosseinzadeh, M. Tajbakhsh, A. Naqinezhad, Essential-Oil and Fatty-Acid Composition, and Antioxidant Activity of Extracts of Ficaria kochii, Chemistry \& biodiversity, 9 (2012) 2732-2741. https://doi.org/10.1002/cbdv.201100389

[5] C. Agyare, A.S. Dwobeng, N. Agyepong, Y.D. Boakye, K.B. Mensah, P.G. Ayande, M. AdarkwaYiadom, Antimicrobial, antioxidant, and wound healing properties of Kigelia Africana (Lam.) Beneth. and Strophanthus hispidus DC. Advances in Pharmacological and Pharmaceutical Sciences, 10 (2013). https://doi.org/10.1155/2013/692613

[6] B. Verdcourt. (1971). Flora of Tropical East Africa. http://creativecommons.org/licenses/by-nc$\mathrm{sa} / 3.0$

[7] B. Sultana, F. Anwar, M. Ashraf, Effect of extraction solvent/technique on the antioxidant activity of selected medicinal plant extracts, Molecules, 14 (2009) 2167-2180.

[8] A. Pandey, S. Tripathi, Concept of standardization, extraction and pre phytochemical screening strategies for herbal drug, Journal of Pharmacognosy and Phytochemistry, 2 (2014) 115-119.

[9] O. O. Odebiyi, E. A. Sofowora, (1978) Phytochemical screening of Nigerian medicinal plants II, Lloydia, 41 (3) 234-246.

[10] W.C. Evans, (2009) Trease and Evans' Pharmacognosy 16th Edition, Elsevier.

[11] A. Banso, J.E. Ngbede, Phytochemical screening and in vitro antifungal properties of Fagara zanthoxyloides. Journal of Food, Agriculture and Environment. 4 (2006) 8-9. https://doi.org/10.1234/4.2006.905

[12] P. Cosa, A.J. Vlietinck, D.V. Berghe, L. Maes, Anti-infective potential of natural products: How to develop a stronger in vitro 'proof-of-concept', Journal of Ethnopharmacology, 106 (2006) 290302. https://doi.org/10.1016/i.jep.2006.04.003

[13] D. Srinivasan, S. Nathan, T. Suresh, P. Lakshmana, Perumalsamy, Antimicrobial activity of certain Indian medicinal plants used in folkloric medicine, Journal of Ethnopharmacology, 74 (2001) 217220.

[14] A.W. Bauer, W.M.W. Wirby, J.C. Sherris, M. Turck, Antibiotic susceptibility test by a standardized single disk method, American Journal of Clinical Pathology. 36 (1966) 493-496.

[15] M.K. Woźniak, L. Laura Banaszkiewicz, M. Marek Wiergowski, E. Ewa Tomczak, M. Kata, B. Szpiech, J. Namieśnik, M. Biziuk1,. Development and validation of a GC-MS/MS method for the determination of 11 amphetamines and 34 synthetic cathinones in whole blood, Forensic Toxicology, 38 (2020) 42-58. https://doi.org/10.1007/s11419-019-00485-y

[16] J. Jakopic, F. Stampar, R. Veberic, The influence of exposure to light on the phenolic content of 'Fuji'apple, Scientia Horticulturae, 123 (2009) 234-239. DOI: 10.1016/i.scienta.2009.09.004 
[17] O.T. Osuntokun, Evaluation of Inhibitory Zone Diameter (IZD), Phytochemical Screening, Elemental Composition and Proximate Analysis of Crude Cleistopholis Patens (Benth.) on Infectious Clinical Isolates, Journal of Molecular Biomarkers \& Diagnosis, 9 (2018) 1-9. https://doi.org/10.4172/2155-9929.1000385

[18] P. Rasoanaivo, C. W. Wright, M. L. Willcox, B. Gilbert, Whole plant extracts versus single compounds for the treatment of malaria: synergy and positive interactions, Malaria journal, 10 (2011)1-12.

[19] H. Wagner, G. Ulrich-Merzenich, Synergy research: approaching a new generation of $\begin{array}{lllll}\text { phytopharmaceuticals and } & 16 & \text { (2009) }\end{array}$ DOI: 10.1016/j.phymed.2008.12.018

[20] A. J. McBain, R. G. Bartolo, C. E. Catrenich, D. Charbonneau, R. G. Ledder, P. Gilbert, Growth and molecular characterization of dental plaque microcosms, Journal of applied microbiology, 94 (2003) 655-664. https://doi.org/10.1046/j.1365-2672.2003.01876.x

[21] E. O. Morente, M. A. Fernández-Fuentes, M. J. G. Burgos, H. Abriouel, R. P. Pulido, A. Galvez, Biocide tolerance in bacteria, International journal of food microbiology, 162 (2013) 13-25. https://doi.org/10.1016/j.ijfoodmicro.2012.12.028

[22] G. McDonnell, A. D. Russell, Antiseptics and disinfectants: activity, action, and resistance, Clinical microbiology reviews, 12 (1999) 147-179. https://doi.org/10.1128/CMR.12.1.147

[23] S. Mamta, S. Jyoti, N. Rajeev, S. Dharmendra, G. Abhishek, Phytochemistry of medicinal plants, Journal of pharmacognosy and phytochemistry, l (2013)168-182,

[24] Richard Cammack, Teresa Atwood, Peter Campbell, Howard Parish, Anthony Smith, Frank Vella, John Stirling, (2008) Oxford dictionary of biochemistry and molecular biology, Oxford University Press. https://doi.org/10.1093/acref/9780198529170.001.0001

[25] H.F. Gemede, N. Ratta, Antinutritional factors in plant foods: potential health benefits and adverse effects, International Journal of Nutrition and Food Sciences, 3 (2014) 284-289.

[26] Oakenfull, D, and Sidhu G. S. (1989). Saponins: In Toxicants of plant origin, Vol. II, Glycosides. 97.

[27] C. Nieman, Influence of trace amounts of fatty acids on the growth of microorganisms, Bacteriological Reviews, 18 (1954)147-163.

[28] T. Tyagi, M. Agarwal, Phytochemical screening and GC-MS analysis of bioactive constituents in the ethanolic extract of Pistia stratiotes L. and Eichhornia crassipes (Mart.) solms, Journal of Pharmacognosy and Phytochemistry, 6 (2017)195-206.

[29] H. R. Knapp, M. A. Melly, Bactericidal effects of polyunsaturated fatty acids, Journal of Infectious Diseases, 154 (1986) 84-94. https://doi.org/10.1093/infdis/154.1.84

[30] K.B. Yoon, A. Joshua, J.A. Jackman, E.R. Valle-González, N.J. Cho, Antibacterial Free Fatty Acids and Monoglycerides: Biological Activities, Experimental Testing, and Therapeutic Applications, International Journal of Molecular Sciences, $19 \quad$ (2018) 1114. https://doi.org/10.3390/ijms19041114

[31] M.P. Cerdeiras, J. Fernández, M. Soubes, S. Vero, F. Ferreira, P. Moyna, I. Olano, A. Vázquez, A new antibacterial compound from Ibicella lutea, Journal of Ethnopharmacology,73 (2000) 521525. https://doi.org/10.1016/s0378-8741(00)00339-1

[32] F. Dilika, P.D. Bremner, J. J. M. Meyer, Antibacterial activity oflinoleic and oleic acids isolated from Helichrysum pedunculatum: a plant used during circumcision rites, Fitoterapia, 71 (2000) 450-452. https://doi.org/10.1016/S0367-326X(00)00150-7

[33] L. J. McGaw, A. K. Jäger, J. Van Staden, Isolation of antibacterial fatty acids from Schotia brachypetala, Fitoterapia, 73 (2002) 431-433. https://doi.org/10.1016/S0367-326X(02)00120$\underline{X}$ 
[34] B.T.S. Yff, K.L. Lindsey, M.B. Taylor, D.G. Erasmus, A.K. Jäger, Thepharmacological screening of Pentanisia prunelloides and the isolation of the antibacterial compound palmitic acid. Journal of Ethnopharmacology. 79 (2002) 101-107. DOI: 10.1016/s0378-8741(01)00380-4

[35] J.B. Harborne, H. Baxter, (1993) Pyrrolizidine Alkaloids. In: Taylor, Phytochemical Dictionary, Bristol, 255-266.

[36] C.W. Sheu, E. Freese, Lipopolysaccharide layer protection of Gram-negative bacteria against inhibition by long-chain fatty acids, Journal of Bacteriology, 115 (1973) 869-875.

[37] J. J. Kabara, Food-grade chemicals for use in designing food preservative systems, Journal of Food Protection, 44 (1981) 633-647. https://doi.org/10.4315/0362-028x-44.8.633

\section{Acknowledgement}

NIL

\section{Funding}

This study was not funded by any grant

\section{Conflict of interest}

None of the authors have any conflicts of interest to declare.

\section{About the License}

(C) The author(s) 2021. The text of this article is open access and licensed under a Creative Commons Attribution 4.0 International License 